\title{
Eleutherococcus humillimus, a New Combination in Chinese Araliaceae
}

\author{
Deng Yunfei \\ South China Institute of Botany, Chinese Academy of Sciences, Guangzhou, \\ Guangdong, 510650, People's Republic of China. yfdeng@scib.ac.cn
}

AbSTRACT. A new combination, Eleutherococcus humillimus (Y. S. Lian \& X. L. Chen) Y. F. Deng. is made.

Key words: Acanthopanax, Araliaceae, China. Eleutherococcus.

Eleutherococcus Maximowicz (1859) is the correct name for the genus previously widely referred to as Acanthopanax (Decaisne \& Planchon) Witte (1861). Nomenclatural problems involving these genera have been discussed by several authors over the years (Hu, 1980; Ohashi, 1987; Hsu \& Pan. 1993; Zhu et al., 1995). Eleutherococcus has about 25 species distributed mainly in northeastern Asia, including China, Korea, and Japan, with some members extending to southwestern Asia (Kim \& Sun, 2000).

Acanthopanax was recognized at the subgeneric rank under Panax L. by Decaisne and Planchon (1854), and was later raised by Witte (1861) to generic rank. Harms (1897: 49) combined both under one genus and adopted the name Acanthopanax, which has been widely used since by many botanists (Harms, 1918; Li, 1942; Hoo \& Tseng, 1978; Philipson, 1979; Shang, 1985a, 1985b). However, the name Acanthopanax does not have priority under the current ICBN (Greuter et al., 2000), and several recent authors (e.g., Hu, 1980; Stone, 1980; Ohashi, 1987; Hsu \& Pan, 1993; Zhu et al., 1995) have accordingly transferred taxa from Acanthopanax to Eleutherococcus.

In 1918 Harms classified the genus into seven sections, namely, sect. Eleutherococcus, sect. Cephalopanax, sect. Euacanthopanax, sect. Zanthoxylopanax, sect. Evodiopanax, sect. Sciadophylloides, and sect. Kalopanax. This system has been accepted by many authors (Hoo \& Tseng, 1978; Shang, 1985a, 1985b; Ohashi, 1987), but section Kalopanax, typified by K. pictus (Thunberg) Nakai, is generally treated as a distinct genus. Several years later, Nakai (1924) elevated section Evodiopanax to generic rank, then Shang et al. (2000) synonymized it with Gamblea C. B. Clarke and made four new combinations. Shang and Huang
(1993) raised section Sciadophylloides to generic rank as Chengiopanax C. B. Shang \& J. Y. Huang with two species, C. fargesii (Franchet) C. B. Shang \& J. Y. Huang and C. sciadophylloides (Franchet \& Savatier) C. B. Shang \& J. Y. Huang. Recognition of the unarmed genera Gamblea and Chengiopanax as distinct from Eleutherococcus, which has spines or prickles, was recently confirmed using ITS sequence data (Wen et al., 2001).

Acanthopanax humillimus Y. S. Lian \& X. L. Chen was described by Lian and Chen (1994) based on collections from Gansu Province, China, but the necessary combination in Eleutherococcus is made here.

Eleutherococeus humillimus (Y. S. Lian \& X. L. Chen) Y. F. Deng, comb. nov. Basionym: Acanthopanax humillimus Y. S. Lian \& X. L. Chen, Acta Bot. Boreal.-Occid. Sin. 14(6): 76. 1994. TYPE: China. Gansu: Lintan Xian, "Lianhua mountain, in locis udis regionis in sylvis," 2700 m, 9 July 1994, Y. S. Lian et al. 94065 (holotype, NWTC).

Distribution. A rare species endemic to southern Gansu and northern Sichuan Provinces of China, in alpine habitats at high elevations (2700$3000 \mathrm{~m})$.

Eleutherococcus humillimus most closely resembles E. giraldii (Harms) Nakai but differs in being a subshrub, only $5-15 \mathrm{~cm}$ tall (vs. $1-3 \mathrm{~m}$ ), with 3 or 4 (rarely 5 ) ovaries and styles (vs. 5 ovaries and styles), the latter connate for ca. 1/5 their length (rather than 1/4-1/2). Eleutherococcus humillimus occurs at high elevations and may be an alpine vicariant of $E$. giraldii.

Additional specimens examined. CHINA. Sichuan: Hongyuan Xian, Shuajingsi, Yakou, alt. $3450 \mathrm{~m}$, in ravine, 8 Oct. 1957, Li Xing 72410 (IBSC, SZ); Hongyuan Xian, Shuajingsi, Yakou, alt. 3400 m, 9 Oct. 1957, Li Xing 72444 (IBSC, SZ); Nanping Xian, Jiuzhaigou, $3200 \mathrm{~m}$, in Picea forest, 25 Sep. 1986, Wu Zhengyi et al. 811 (KUN): Nanping xian, Jiuzhaigou, Changhai, $2800 \mathrm{~m}$, in Picea forest, 26 Sep. 1986, Wu Zhengyi et al. 982 (KUN); Nanping Xian, Jiuzhaigou, in forest, 25 Sep. 1986, Wu Zhengyi et al. 1110 (KUN); Zoigê (Ruoergai) Xian, Baxi gongshe, 
Yangyugou, in Picea forest, alt. 3100 m, 28 June 1975 , Chengdu Biological Institute 10063 (IBSC). Gansu: Dangchang xian, Daheba, in subalpine shrubby, alt. 3000 m, 24 Sep. 1979, Lian Yongshan 790922 (NWTC); Tewo xian, Lazikou Linchang, in the forest, on the rock, alt. 3000 m, 24 July 1980, Lian Yongshan et al. 800222 (NWTC).

Acknowledgments. I thank Nicholas Turland (MO) for editorial help with the manuscript. I am grateful to two anonymous reviewers for their comments. This work was partly supported by a grant from the Director Foundation of the South China Institute of Botany, CAS.

\section{Literature Cited}

Decaisne, J. \& J.-E. Planchon. 1854. Esquisse d'une monographie des Araliacées. Rev. Hort., sér. 4, 3: 104-109.

Greuter, W., J. McNeill, F. R. Barrie, H. M. Burdet, V. Demoulin, T. S. Filgueiras, D. H. Nicolson, P. C. Silva, J. E. Skog, P. Trehane, N. J. Turland \& D. L. Hawksworth (editors). 2000. International Code of Botanical Nomenclature (Saint Louis Code). Regnum Veg. 138.

Harms, H. 1894-1897. Araliaceae. Pp. 1-48 [1894], 4962 [1897] in: A. Engler \& K. Prantl (editors), Die natürlichen Pflanzenfamilien, 3(8). Wilhelm Engelmann, Leipzig.

— 1918. Ubersicht über die Arten der Gattung Acanthopanax. Mitt. Deutsch. Dendrol. Ges. 27: 1-39 + t. 1-8b,

Hoo, G. \& C. J. Tseng. 1978. Araliaceae. Pp. 1-190 in Flora Reipublicae Popularis Sinicae, 54. Science Press. Beijing.

Hsu, P. S. \& S. L. Pan. 1993. Additional transfers of Chinese Acanthopanax to Eleutherococcus (Araliaceae). Sida 15: 593-595.

Hu, S. Y. 1980. Eleutherococcus vs. Acanthopanax. J. Arnold Arbor. 61: 107-111.
Kim, C. H. \& B. Y. Sun. 2000. New taxa and combinations in Eleutherococcus (Araliaceae) from eastern Asia. Novon 10: 209-214.

Li, H. L. 1942. The Araliaceae of China. Sargentia 2: 1134

Lian, Y. S. \& X. L. Chen. 1994. A new species of the genus Acanthopanax Miq. Acta Bot. Boreal.-Occid. Sin. 14(6): 76-77.

Maximowicz, C. J. 1859. Primitiae florae amurensis. Mém. Acad. Imp. Sci. St.-Pétersbourg Divers Savans 9.

Nakai, T. 1924. Araliaceae imperii Japonici. J. Arnold Arbor. 5: 1-36.

Ohashi, H. 1987. Eleutherococcus (Araliaceae)-A new system and new combinations. J. Jap. Bot. 62: 353-361.

Philipson, W. R. 1979. Araliaceae-I. Pp. 1-105 in C. G. G. J. van Steenis (editor), Flora Malesiana, 9. Martinus Nijhoff and Dr. W. Junk Publishers, The Hague.

Shang, C. B. 1985a. Araliaceae. Pp. 1720-1813 in W. C. Cheng (editor), Sylva Sinica, 2. Chinese Forestry Press. Beijing.

1985b. New taxa and some revisions about the Araliaceae of China. J. Nanjing Inst. Forest. 2: 15-28. \& J. Y. Huang. 1993. Chengiopanax-A new genus of Araliaceae. Bot. Bull., Harbin. 13(1): 44-49.

. P. P. Lowry II \& D. G. Frodin. 2000. A taxonomic revision and re-definition of the genus Gamblea (Araliaceae). Adansonia, sér. 3, 22: 45-55.

Stone, B. C. 1980. A nomenclatural change in Malaysian Araliaceae: Eleutherococcus malayanus (Henderson) comb. nov. instead of Acanthopanax malayanus Hend. Malaysian Forester 43: 395.

Wen, J., G. M. Plunkett, A. Mitchell \& S. Wagstaff. 2001. Evolution of Araliaceae: A phylogenetic analysis based on the ITS sequences of nrDNA. Syst. Bot. 26: 144167.

Witte, H. 1861. Les Araliacées des jardins Hollandais. Ann. Hort. Bot. 4: 87-95.

Zhu, X. Y.. S. Ge \& D. Y. Hong. 1995. A critical note on the scientific name Acanthopanax Miq[.] and several new combinations. Bull. Bot. Res., Harbin 15: 441443. 


\section{$2 \mathrm{BHL}$ Biodiversity Heritage Library}

Deng, Yunfei. 2003. "Eleutherococcus humillimus, a New Combination in Chinese Araliaceae." Novon a journal of botanical nomenclature from the Missouri Botanical Garden 13, 305-306. https://doi.org/10.2307/3393262.

View This Item Online: https://www.biodiversitylibrary.org/item/14673

DOI: https://doi.org/10.2307/3393262

Permalink: https://www.biodiversitylibrary.org/partpdf/122151

\section{Holding Institution}

Missouri Botanical Garden, Peter H. Raven Library

\section{Sponsored by}

Missouri Botanical Garden

\section{Copyright \& Reuse}

Copyright Status: In copyright. Digitized with the permission of the rights holder.

License: http://creativecommons.org/licenses/by-nc-sa/3.0/

Rights: https://biodiversitylibrary.org/permissions

This document was created from content at the Biodiversity Heritage Library, the world's largest open access digital library for biodiversity literature and archives. Visit BHL at https://www.biodiversitylibrary.org. 